\title{
Perancangan Video Infografis Peta Komplek Perkantoran Terpadu Kabupaten Boyolali dan Pelayanan Dinas Kepemerintahan Berbentuk Motion Graphic 3 Dimensi
}

\author{
Agatha Nareswari Kemara ${ }^{1}$, Michael Bezaleel Wenas ${ }^{2}$ \\ Universitas Kristen Satya Wacana \\ 692012048@student.uksw.edu
}

\begin{tabular}{ll}
\hline ARTICLE INFO & ABSTRACT \\
\hline $\begin{array}{l}\text { Article history: } \\
\text { Received: 20 Oktober } 2017\end{array}$ & $\begin{array}{l}\text { Boyolali Regency integrated office is an area consists of many single } \\
\text { Revised: 1 November } 2017\end{array}$ \\
Accepted: 20 November 2017 & $\begin{array}{l}\text { main responsibiliy and functions. The modification of those regional } \\
\text { warking units in 2016 resulted in alteration of offices map as well as }\end{array}$ \\
\hline Keywords: & the main responsibility and functions. Lack of media availablility \\
Infographic & that informs this modification confuses people when they have some \\
Map & needs in those government offices. Here is an interesting 3D \\
Office & infographic, presented in simple language, to provide clear \\
Boyolali & understanding to the people. \\
Responsibility &
\end{tabular}

\section{PENDAHULUAN}

Dinas pemerintahan merupakan salah satu unsur penting bagi terbentuknya sebuah otonomi daerah. Dinas pemerintahan mempunyai fungsi memberikan pelayanan publik yang di butuhkan masyarakat seperti pelayanan dalam bidang pendidikan, kesehatan, kependudukan dan lainnya. Dengan berbedanya jenis pelayanan yang diberikan maka berbeda juga dinas pemerintahan yang melayanin masyarakat.

Kabupaten Boyolali merupakan salah satu kabupaten yang berada di provinsi Jawa Tengah yang cukup pesat perkembangan daerahnya. Berbagai sarana ruang publik dibangun guna menarik minat investor untuk berinvestasi di Kabupaten Boyolali. Salah satu pembangunan yang dilakukan oleh pemerintah Kabupaten Boyolali adalah pembangunan komplek perkantoran terpadu (http://www.antarajateng.com/detail/agustus-pemkab-boyolali-tempati-kantor-baru-.html ).

Komplek perkantoran terpadu merupakan sebuah wilayah yang terdiri dari kantor-kantor satuan kerja perangkat daerah Kabupaten Boyolali. Dibangunnya komplek perkantoran terpadu tersebut bertujuan untuk mempermudah masyarakat dalam mencari kantor pemerintahan dan juga peningkatan pelayanan karena sebelumnya kantor-kantor pemerintahan Kabupaten Boyolali letaknya berjauhan satu sama lain. Tapi minimnya media informasi tentang peta lokasi kantor pemerintah dan juga tugas pokok dan fungsi satuan kerja perangkat daerah Kabupaten Boyolali menjadikan kurangnya pengetahuan dari masyarakat Boyolali akan hal tersebut. Terlebih lagi dengan adanya perubahan pada satuan kerja perangkat daerah pada tahun 2016 yang 
mengakibatkan adanya perubahan pada satuan kerja perangkat daerah serta tugas pokok dan fungsinya. Media yang disediakan oleh pemerintah tentang lokasi perkantoran hanya berupa sign system sebelum adanya perubahan satuan kerja perangkat daerah tanpa adanya media yang menjelaskan tugas pokok dan fungsi dari masing-masing satuan kerja perangkat daerah.

Berdasarkan permasalahan yang ada maka akan dirancang sebuah infografis tentang peta komplek perkantoran terpadu serta tugas pokok dan fungsi satuan kerja perangkat daerah Kabupaten Boyolali menggunakan motion graphic 3 dimensi. Penggunaan infografis dianggap memudahkan sebagian orang untuk mempelajari sesuatu karena merupakan penggabungan antara gambar dan materi yang dikemas secara menarik dan tidak membosankan. Infografis semakin banyak digunakan oleh berbagai pihak termasuk pemerintah dalam mensosialisasikan informasi. Infografis dapat digunakan untuk memberikan informasi tentang pelayanan yang diberikan dinas-dinas kepemerintahan Kabupaten Boyolali. Digunakannya motion graphic 3 dimensi dimaksudkan agar informasi yang di sampaikan lebih jelas dan menarik, dan juga penggunaan grafis 3 dimensi dapat mendukung penggambaran bentuk fisik dari bangunan perkantoran dinas pemerintahan yang ada dengan lebih detail.

\section{PEMBAHASAN}

\subsection{Tinjauan Pustaka}

Penelitian yang pernah dilakukan sebelumnya yaitu "Perancangan Video Infografis P.T. Bumi Artha Nugraha Sebagai Media Informasi dengan Teknik Motion Graphic". Penelitian ini dilakuakn oleh Rizky Utari dan Dhani Ariatmanto. Video infografis P.T. Bumi Artha Nugraha ini dibuat dengan tujuan memberikan informasi mengenai prestasi proyek yang sudah selesai maupun yang sedang berjalan dan juga potensi yang ada di lokasi pembangunan perumahan tersebut. Tujuan lainnya adalah membantu branding P.T. Bumi Artha Nugraha dengan memanfaatkan perkembangan teknologi informasi. Target dari video infografis ini adalah masyarakat Yogyakarta. Metode dalam pengumpulan data yang digunakan adalah Data Primer dan Sekunder. Data primer didapat dari wawancara dengan manajer utama dan direktur utama. Sedangkan data sekunder didapat dari studi literatur berdasarkan studi pustaka, internet maupul referensi lainnya yang valid dan terpercaya. Hasil penelitian yang dilakukan yaitu memberikan informasi tentang P.T. Bumi Artha Nugraha dalam bentuk video infografis (Rizky, 2014).

Penelitian selanjutnya adalah penelitian yang dilakukan oleh Tri Ayu Anita yang berjudul perancangan visual branding Kabupaten Boyolali melalui desain komunikasi visual. Penelitian ini bertujuan untuk merancang dan membuat sebuah komunikasi visual yang bermutu sehingga 
memberikan kesan dan informasi tentang Kabupaten Boyolali. Metode yang digunakan dalam penelitian ini adalah pengumpulan data yang diperoleh dari kantor, dinas, instansi atau lembaga yang berkaitan dengan penelitian. Hasil dari penelitian ini merupakan visual branding dari Kabupaten Boyolali seperti logo, slogan, mascot, amlop, kertas surat dan visual branding lainnya (Anita, 2006).

Dari kedua penelitian yang ada, perbedaan dari penelitian ini dengan penelitian terdahulu adalah perancangan sebuah infografis dengan menggunakan motion graphic 3 dimensi sebagai bentuk penyampaian informasi yang lebih menarik dengan tujuan memberikan informasi kepada masyarakat atau target audience tentang peta komplek perkantoran terpadu Kabupaten Boyolali dan pelayanan dinas kepemerintahannya.

Media informasi menurut Sobur adalah alat untuk mengumpulkan serta menyusun kembali sebuah informasi sehingga menjadi bahan yang bermanfaat bagi penerima informasi, dan merupakan alat-alat grafis, fotografis atau elektronis untuk menangkap, memproses, serta menyusun kembali informasi visual (http://www.seputarpendidikan.com/2016/04/pengertianmedia-informasi-menurut-para-ahli.html).

Media informasi dapat dibagi menjadi bebrapa kelompok yaitu :

- Media lini atas

Merupakan media yang tidak langsugn bersentuhan dengan target audiens serta jumlahnya terbatas tetapi jangkauan target yang lurus, seperti billboard, iklan televisi, dan iklan radio.

- Media lini bawah

Merupakan media iklan yang tidak disampaikan atau disiarkan melalui media massa serta jangkauan target hanya berfokus pada satu titik atau daerah, seperti brosur, poster, flyer, dan sign system.

- Media cetak dapat berupa brosur, Koran, majalah, poster, pamphlet, dan spanduk.

- Media elektronik

Media ini dapat disampaikan melalui radio, kaset, kamera, handphone, dan internet (http://www.seputarpendidikan.com/2016/04/pengertian-media-informasi-menurut-paraahli.html).

Infografis berasal dari kata infographics dalam Bahasa Inggris yang merupakan singkatan dari Information + Graphics adalah bentuk visualisasi data yang menyampaikan informasi kompleks kepada pembaca agar dapat dipahami dengan lebih mudah dan cepat. Salah satu alasannya adalah informasi yang ditangkap secara visual akan diproses sekaligus oleh otak, 
berbeda dengan informasi yang disampaikan via teks, dimana informasi akan diproses secara linear (dari awal kalimat hingga ke ujung kalimat). Membuat infografis sendiri adalah percampuran antara skill desain, analisis informasi, dan storytelling. Ketiga komponen tersebut adalah kunci dari infografis yang maksimal. Infografis mempunyai beberapa jenis yaitu:

- Infografis statis

Infografis dalam bentuk gambar yang tidak bergerak. Seperti infografis pada media cetak ataupun website. Infografis statis merupakan infografis yang paling umum. Infografis statis dapat diaplikasikan pada berbagai media seperti misalnya pada event pameran.

- Infografis animasi

Infografis animasi atau infographic animated adalah infografis dalam bentuk video animasi, baik 2 dimensi atau 3 dimensi. Infografis ini dapat digunakan pada televisi ataupun media online seperti YouTube atau Vimeo. Infografis animasi dapat lebih menarik karena selain elemen visual juga menggunakan motion (pergerakan) dan audio (music / sound effect) yang dapat memperkuat informasi/pesan yang ingin disampaikan. Untuk membuat infografis animasi diperlukan keahlian yang beragam seperti director, animator, illustrator, music artist, voice over, dan lainnya.

- Infografis interaktif

Infografis interaktif adalah infografis yang ditampilkan pada website dan pengguna dapat berinteraksi dengan informasi yang ditampilkan melalui user interface yang telah didesain. Dengan infografis interaktif pengguna dapat sesuai keinginan mengeksplorasi informasi yang ingin didapatkan. Pada pihak pembuat infografis pun dapat merancang tampilan agar informasi yang disampaikan seefektif mungkin sesuai perilaku user. Untuk membuat infografis interaktif diperlukan keahlian seperti desainer, illustrator, UI/UX desainer, dan programmer. Pada infografis interaktif programmer/developer memiliki peran yang penting agar infografis yang sudah didesain dapat berfungsi dengan maksimal dan tanpa masalah (http://houseofinfographics.com/apa-itu-infografis/).

Menurut Angga Prabawa motion graphic adalah teknik untuk menggerakkan still images sehingga objek terlihat tidak membosankan, namun terlihat dinamis dan menarik. Terdapat dua metode dalam pembuatan motion graphic yakni dengan menggerakkan gambar dan menggabungkan gambar yang memiliki kontinuitas sehingga terlihat bergerak. [6] Motion Graphics adalah percabangan dari seni desain grafis yang merupakan penggabungan dari, ilustrasi, tipografi, fotografi dan videografi dengan menggunakan teknik animasi. Motion Graphics terdiri dari dua kata, motion yang berarti Gerak dan graphics atau yang sering kita 
kenal dengan istilah grafis. Dari asal muasal pengertian dua kata tersebut, bisa dikatakan bahwa Motion Graphics, juga dapat disebut dengan istilah grafis gerak (Prabawa, 2014).

3 Dimensi merupakan presentasi visual pada sebuah permukaan. Grafik 2D memiliki sumbu x dan y, sedangkan grafik 3D memiliki sumbu x, y dan z. Perbedaan yang diberikan oleh grafik 3D adalah adanya efek kedalaman. Kadang dalam mengembangkan gambar, gambar yang dibangun dalam bentuk 2D lebih jelas dan lebih menyerupai bentuk asli dibandingkan gambar yang dibangun dalam bentuk 3D. Selain itu disebutkan beberapa gambaran yang dibangun dalam bentuk 3D dapat menyebabkan beban kognitif pengguna, atau mental dari pengguna memiliki interpretasi yang berbeda akan gambaran yang dibangun dengan gambaran yang sesungguhnya. Namun disebutkan bahwa gambaran dalam bentuk 3D baik digunakan pada kasus-kasus tertentu seperti untuk merepresentasikan objek yang bergerak, merepresentasikan gambar yang memiliki komponen 3D, dan untuk sistem yang dibangun dengan tujuan yang sudah pasti dan khusus, seperti ingin mengajarkan bagaimana bentuk bumi yang sesungguhnya. Bagian-bagian dalam sebuah objek 3 dimensi yaitu:

- Vertex. Dalam objek 3 dimensi, Vertex (plural: Vertices), dapat diistilahkan sebagai titik (jamak: Simpul), adalah titik di mana dua atau lebih garis lurus bertemu.

- Edge. Dalam obyek 3 dimensi, Edge, dapat diistilahkan sebagai tepi, adalah ruas garis yang menghubungkan dua simpul.

- Face. Dalam objek 3d, Face, dapat diistilahkan sebagai wajah/sisi/permukaan, adalah salah satu permukaan individual dari sebuah benda padat (http://oprekzone.com/pengertian-objek-3-dimensi/).

Komplek perkantoran terpadu Kabupaten Boyolali merupakan sebuah komplek perkantoran dari dinas-dinas pemerintahan yang ada di Kabupaten Boyolali. Komplek perkantoran terpadu itu terletak di Kemiri, Mojosongo, Boyolali. Selain dinas pemerintahan, sejumlah kantor badan daerah yang dipindahkan ke komplek tersebutt yaitu Badan Perencanaan, Penelitian dan Pengembangan Daerah, Badan Keuangan Daerah, Badan Kepegawaian, Pendidikan dan Pelatihan Daerah, Badan Penanggulangan Bencana Daerah dan juga Satuan Polisi Pamong Praja. Dinas-dinas pemerintah yang sekarang berada dalam komplek perkantoran terpadu antara lain Dinas Pendidikan dan Kebudayaan, Dinas Pekerjaan Umum dan Penataan Ruang, Dinas perumahan dan Kawasan Permukiman, Dinas Sosial, Dinas Pengendalian Penduduk, Keluarga Berencana, Pemberdayaan Perempuan dan Perlindungan Anak, Dinas Ketahanan Pangan, Dinas Lingkungan Hidup, Dinas Kependudukan dan Pencatatan Sipil, Dinas 
Pemberdayaan Masyarakat, Dinas Perhubungan, Dinas Informasi dan Informatika, Dinas Koperasi dan Tenaga Kerja, Dinas Pemuda, Olahraga, dan Pariwisata, Dinas Kearsipan dan Perpustakaan, Dinas Pertnian, Dinas Peternakan dan Perikanan, serta Dinas Perdagangan dan Perindustrian. Terdapan juga kantor Kesbangpolinmas (www.boyolali.go.id).

Selain kantor satuan kerja perangkat daerah Kabupaten Boyolali, dalam komplek perkantoran terpadu Boyolali juga terdapat pula rumah ibadah agama-agama yang diakui di Indonesia. Lingkungannya sudah mulai ditumbuhi tanaman agar suasana komplek perkantoran terpadu tersebut cukup rindang. Area trotoar tidak boleh dipakai pedagang kaki lima untuk berjualan karena sudah disediakan area di alun-alun Boyolali. Area tersebut tidak pernah sepi pengunjung pada sore hari untuk menghabiskan waktu.

\subsection{Metode Penelitian}

Metode yang dilakukan dalam perancangan ini adalah metode kualitaif. Dasar penelitian kualitatif adalah konstruktivisme yang berasumsi bahwa kenyataan itu berdimensi jamak, interaktif dan suatu pertukaran pengalaman sosial yang diinterprestasikan oleh setiap individu (Sukmadinata, 2012). Metode kualitatif bersifat fleksibel dan berubah-ubah sesuai kondisi lapangan dengan pengambilan data, metode kualitatif merupakan metode studi menggunakan teknik pengumpulan data langsung dari orang dalam lingkungan alamiahnya dalam bentuk wawancara (Noval, 2015). Sedangkan strategi yang digunakan dalam penelitian ini linear strategy atau strategi garis lurus yang menetapkan urutan logis pada tahapan yang sederhana dan relatif mudah dipahami komponennya (Sarwono, dkk, 2007).

Tahapan pertama yang dilakukan adalah mengidentifikasi masalah. Identifikasi masalah merupakan suatu tahap permulaan dari penguasaan masalah dimana objek dalam suatu jalinan tertentu dapat kenali sebagai suatu masalah (Usman dan Purnomo, 2008). Berdasarkan observasi yang dilakukan di komplek perkantoran terpadu Kabupaten Boyolali diketahui bahwa kurangnya media informasi yang ada di daerah komplek perkantoran terpadu Kabupaten Boyolali terkait dengan peta komplek perkantoran terpadu Kabupaten Boyolali dan juga tugas pokok dan fungsi dari satuan kerja perangkat daerah. Media informasi yang di pasang pada pintu masuk masih merupakan denah dari komplek perkantoran terpadu yang lama. Hal ini diperkuat dengan wawancara Kepala Bidang Informasi dan Komunikasi Publik Diskominfo Kabupaten Boyolali Bapak Sarwanto jika kurangnya media informasi di komplek perkantoran terpadu Kabupaten Boyolali. Terlebih lagi dengan adanya pengubahan dan pemisahan satuan kerja perangkat daerah yang ada di Kabupaten Boyolali. Observasi juga dilakukan dengan melakukan wawancara kepada masyarakat Kabupaten Boyolali yang sedang mengurus keperluan di komplek 
perkantoran Kabupaten Boyolali. Hasil yang didapat bahwa masyarakat Boyolali kesulitan mencari letak kantor dinas dan juga terjadi kesalahan karena adanya perubahan dan pemisahan satuan kerja perangkat daerah di Kabupaten Boyolali.

Berdasarkan dengan identifikasi masalah yang didapat maka dilakukan tahap kedua yaitu pengumpulan data mengenai komplek perkantoran terpadu Kabupaten Boyolali. Pengumpulan data dilakukan dengan wawancara kepada Bapak Sarwanto selaku Kepala Bidang Informasi dan Komunikasi Publik Dinas Komunikasi dan Informatika Kabupaten Boyolali. Hasil wawancara yang didapat yaitu company profile Kabupaten Boyolali dan juga foto dan video komplek perkantoran terpadu Kabupaten Boyolali. Pengumpulan data selanjutnya yang dilakukan dengan mencari data melalui website maupun data yang dimiliki oleh Badan Perencanaan, Penelitian dan Pengembangan Daerah. Dari pengumpulan data didapatkan Peraturan Daerah Kabupaten Boyolali nomor 16 tahun 2016 yang mengatur tentang Pembentukan dan Susunan Perangkat Daerah. Didalam peraturan daerah itu terdapat tugas pokok dan fungsi dari setiap satuan kerja perangkat daerah yang terdapat di Kabupaten Boyolali.

Data lain yang didapat adalah tugas dari seorang bupati (http://pemerintah.net/tugaswewenang-kewajiban-dan-hak-kepala-daerah-dan-wakil-kepala-daerah). Data berikutnya adalah tugas dan fungsi dari Dewan Perwakilan Rakyat (http://www.edukasippkn.com/2016/06/kedudukanfungsi-tugas-wewenang-dan-hak.html). Selanjutnya adalah data tentang tugas pokok dan fungsi dari Kesatuan Bangsa dan Politik (http://kesbangpoljateng.com/portal/profile/tupoksi/). Data lain yang didapat terkait dengan peraturan bupati Boyolali yaitu Peraturan Bupati Boyolali nomor 76 tahun 2016 tentang Uraian Tugas Jabatan Eselon pada Badan Keuangan Daerah Kabupaten Boyolali, Peraturan Bupati Boyolali nomor 52 tahun 2016 tentang Uraian Tugas Jabatan Eselon pada Sekretariat Daerah Kabupaten Boyolali, Peraturan Bupati Boyolali nomor 74 tahun 2016 tentang Uraian Tugas Jabatan Eselon pada Satuan Polisi Pamong Praja Kabupaten Boyolali, Peraturan Bupati Boyolali nomor 75 tahun 2016 tentang Uraian Tugas Jabatan Eselon pada badan Perencanaan, Penelitian, dan Pengembangan Daerah Kabupaten Boyolali, Peraturan Bupati Boyolali nomor 54 tahun 2016 tentang Uraian Tugas Jabatan Eselon pada Inspektorat Kabupaten Boyolali, Peraturan Bupati Boyolali nomor 77 tahun 2016 tentang Uraian Tugas Jabatan Eselon pada Badan Kepegawaian, Pendidikan dan Pelatihan Daerah Kabupaten Boyolali, Peraturan Bupati Boyolali nomor 55 tahun 2016 tentang Uraian Tugas Jabatan Eselon pada Dinas Pendidikan dan Kebudayaan Kabupaten Boyolali, Peraturan Bupati Boyolali nomor 61 tahun 2016 tentang Uraian Tugas Jabatan Eselon pada Dinas Ketahanan Pangan Kabupaten Boyolali, Peraturan Bupati Boyolali nomor 64 tahun 2016 tentang Uraian Tugas Jabatan Eselon 
pada Dinas Pemberdayaan Masyarakat dan Desa Kabupaten Boyolali, Peraturan Bupati Boyolali nomor 67 tahun 2016 tentang Uraian Tugas Jabatan Eselon pada Dinas Koperasi dan Tenaga Kerja Kabupaten Boyolali, Peraturan Bupati Boyolali nomor 73 tahun 2016 tentang Uraian Tugas Jabatan Eselon pada Dinas Perdagangan dan Perindustrian Kabupaten Boyolali, Peraturan Bupati Boyolali nomor 59 tahun 2016 tentang Uraian Tugas Jabatan Eselon pada Dinas Sosial Kabupaten Boyolali, Peraturan Bupati Boyolali nomor 62 tahun 2016 tentang Uraian Tugas Jabatan Eselon pada Dinas Lingkungan Hidup Kabupaten Boyolali, Peraturan Bupati Boyolali nomor 68 tahun 2016 tentang Uraian Tugas Jabatan Eselon pada Dinas Penanaman Modal dan Pelayanan Terpadu Satu Pintu Kabupaten Boyolali, Peraturan Bupati Boyolali nomor 71 tahun 2016 tentang Uraian Tugas Jabatan Eselon pada Dinas Pertanian Kabupaten Boyolali, Peraturan Bupati Boyolali nomor 60 tahun 2016 tentang Uraian Tugas Jabatan Eselon pada Dinas Pengendalian Penduduk, Keluarga Berencana, Pemberdayaan Perempuan dan Perlindungan Anak Kabupaten Boyolali, Peraturan Bupati Boyolali nomor 40 tahun 2016 tentang Uraian Tugas Jabatan Eselon pada Dinas Kependudukan dan Pencatatan Sipil Kabupaten Boyolali, Peraturan Bupati Boyolali nomor 66 tahun 2016 tentang Uraian Tugas Jabatan Eselon pada Dinas Komunikasi dan Informatika Kabupaten Boyolali, Peraturan Bupati Boyolali nomor 69 tahun 2016 tentang Uraian Tugas Jabatan Eselon pada Dinas Pemuda, Olahraga dan Pariwisata Kabupaten Boyolali, Peraturan Bupati Boyolali nomor 72 tahun 2016 tentang Uraian Tugas Jabatan Eselon pada Dinas Peternakan dan Perikanan Kabupaten Boyolali.

Dari data yang didapat maka dirancang sebuah Video Infografis Peta Komplek Perkantoran Terpadu Kabupaten Boyolali serta Tugas Pokok dan Fungsi Satuan kerja Perangkat Daerah Berbentuk Motion Graphic 3 Dimensi. Proses perancangan yang dilakukan dalam pembuatan infografis terdiri dati tiga tahap yaitu pra produksi, produksi dan paska produksi.

Media yang dirancang ini dihadirkan sebagai media informasi peta komplek perkantoran terpadu Kabupaten Boyolali serta tugas pokok dan fungsi satuan kerja perangkat daerah yang ada di Kabupaten Boyolali. Media ini dirancang untuk masyarakat Boyolali dengan jenjang umur 1760 tahun. Alur perancangan infografis ini dimulai dengan membuat konsep tentang infografis yang dibuat. Konsep yang akan digunakan dalam media informasi ini adalah menampilkan peta komplek perkantoran terpadu Kabupaten Boyolali dan juga tampilan bangunan yang ada di komplek tersebut serta informasi tentang tugas pokok dan fungsi dari satuan kerja perangkat daerah yang ada di komplek perkantoran terpadu Kabupaten Boyolali. Komplek perkantoran terpadu ini akan digambarkan berada dalam satu pulau sendiri untuk menggambarkan lingkup perkantoran tersebut. Pengambilan gambar dalam infografis ini menggunakan tiga teknik yaitu 
high angle, normal angle, dan slanted angle (Ascher, 1999). Digunakannya sudut pengambilan gambar tersebut memiliki fungsi agar dapat menampilkan objek dari sudut yang berbeda-beda sehingga yang melihat dapat memiliki gambaran yang lebih jelas terhadap objek. Dalam media informasi ini peta komplek perkantoran terpadu Kabupaten Boyolali akan digambarkan dari atas dengan high angle agar penonton dapat mengetahui peta komplek perkantoran dengan lebih jelas. Kemudian bangunan perkantoran akan di lihat dari depan dengan normal angle dengan tujuan menampilkan bagian depan dari bangunan. Lalu bangunan akan diperlihatkan dari sisi samping atau slanted angle agar sisi samping dari bangunan-bangunan tersebut dapat terlihat dengan jelas. Pada bagian opening akan menampilkan nama dari satuan kerja perangkat daerah dan juga peta komplek perkantoran terpadu Kabupaten Boyolali secara keseluruhan. Selanjutnya menampilkan peta komplek perkantoran dari atas bagian depan untuk menunjukkan nama jalan dan are sekitar dari gedung kantor, lalu kemudian menampilkan setiap kantor satuan kerja perangkat daerah yang ada di komplek perkantoran terpadu Kabupaten Boyolali. Transisi yang digunakan dalam media informasi ini adalah zoom in dan zoom out. Alasan digunakannya transisi ini adalah karena selain menggambarkan detail dari bangunan setiap satuan kerja perangkat daerah juga diperlihatkan letak atau posisi dari masing-masing kantor yang diperlihatkan dari atas.

Kemudian tahap kedua dilanjutkan dengan pembuatan storyboard yang berfungsi untuk memberikan gambaran tentang bagaimana nantinya infografis ini akan dibuat yang berisi bangunan-bangunan yang ada di komplek perkantoran terpadu Kabupaten Boyolali dan juga informasi yang akan dicantumkan dalam infografis tersebut berupa tugas pokok dan fungsi dari dinas yang ada di komplek perkantoran tersebut. Perancangan storyboard dari infografis ini dapat dilihat pada Gambar 1.
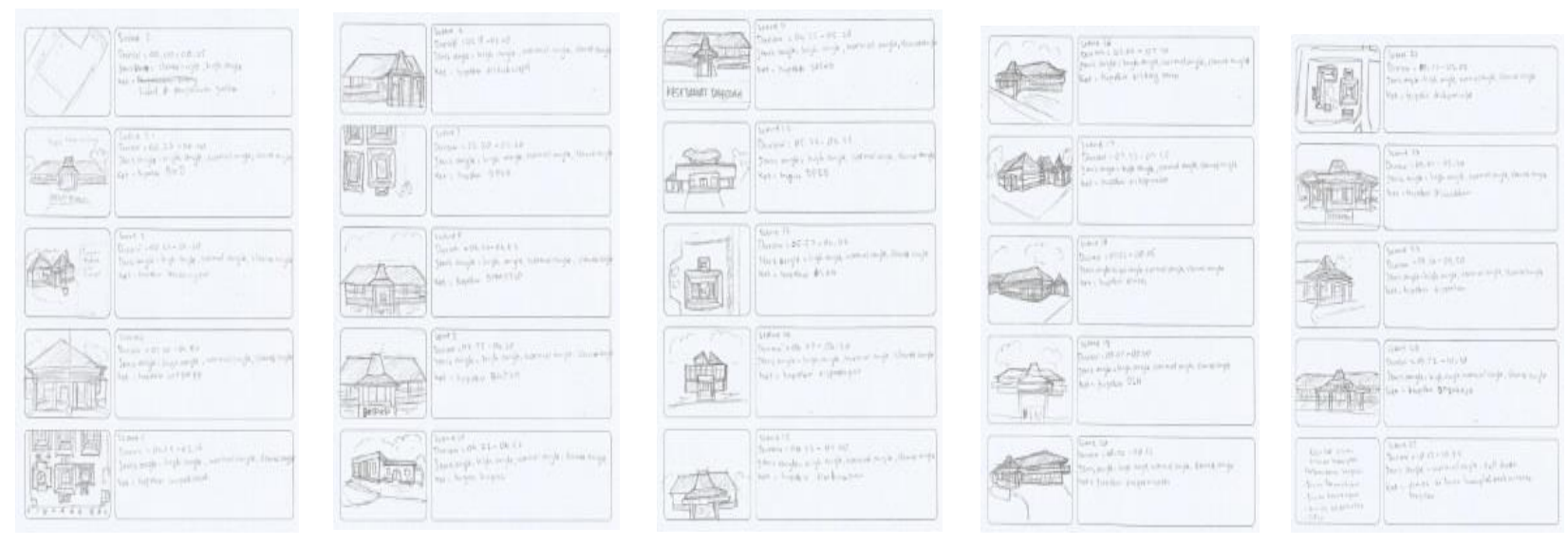

Gambar 1. Storyboard infografis 
Tahap storyboard merupakan tahapan terakhir pada pra produksi. Tahapan berikutnya dengan tahap produksi. Pada tahap produksi dimulai dengan proses modeling objek-objek bangunan di komplek perkantoran terpadu Kabupaten Boyolali. Modeling merupakan proses pembuatan benda 3 dimensi berdasarkan objek nyata maupun tidak. Proses modeling dimulai dengan mengubah peta 2 dimensi komplek perkantoran menjadi 3 dimensi yang dapat dilihat pada Gambar 2.
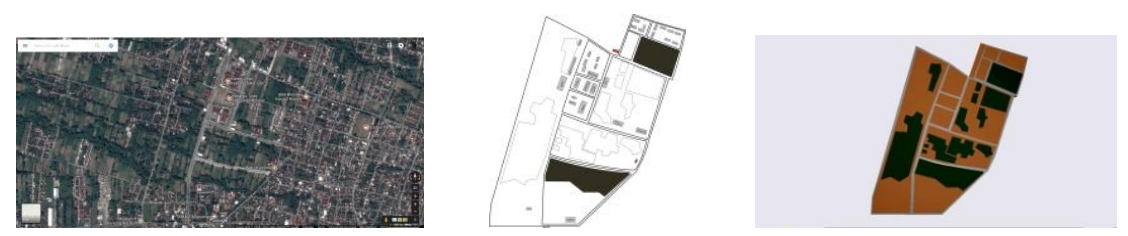

Gambar 2. Modeling peta 2 dimensi menjadi 3 dimensi

Selanjutnya modeling dilakukan pada bangunan-bangunan kantor yang ada di komplek perkantoran terpadu Kabupaten Boyolali. Modeling dilakukan dengan meniru objek nyata dari bangunan kantor yang didapat dengan proses pengambilan gambar secara langsung dan juga dengan proses pengambilan data pada Dinas Komunikasi dan Informatika Kabupaten Boyolali serta pengambilan gambar melalui Google Earth untuk mendapatkan angle yang tidak bisa di dapat dengan proses pengambilan gambar secara langsung. Model 3 dimensi yang telah dibuat dapat dilihat pada Gambar 3.
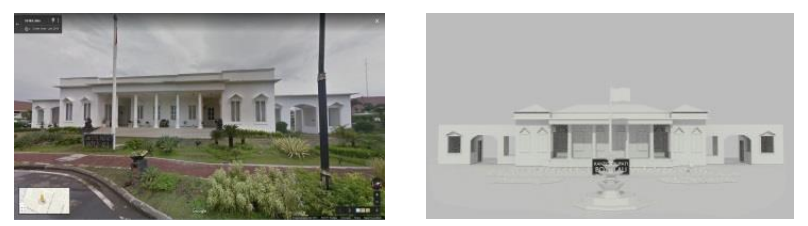

Gambar 3. Modeling Kantor Bupati Boyolali dan Gedung DPRD Boyolali

Setelah proses modeling selesai maka proses selanjutnya yang dilakukan adalah animating camera untuk menentukan sudut pengambilan gambar yang sesuai untuk media informasi ini. Pada proses ini terdapat tiga sudut pengambilan gambar yang digunakan yaitu tampak dari atas, tampak dari depan dan tampak dari samping bangunan. Proses animating camera yang telah dibuat dapat dilihat pada Gambar 4.
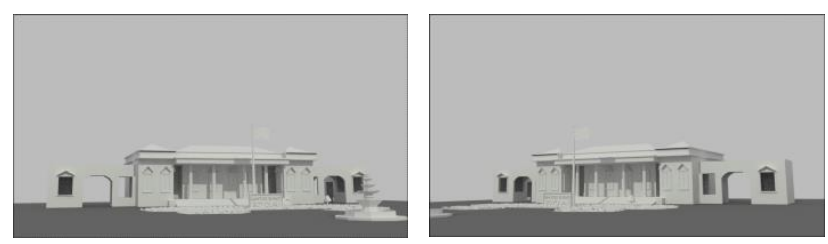

Gambar 4. Proses animating camera 
Kemudian setelah semua bangunan yang ada telah diubah menjadi model 3 dimensi dan dilakukan animating camera, maka tahapan selanjutnya adalah proses materialing. Materialing adalah proses pemberian warna pada model-model objek yang ada pada komplek perkantoran terpadu Kabupaten Boyolali. Warna yang digunakan menyesuaikan dengan warna asli dari bangunan. Model 3 dimensi yang sudah diberi material dapat dilihat pada Gambar 6 .
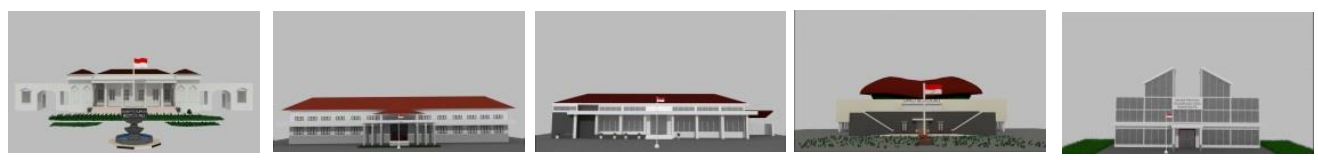

Gambar 6. Model 3 dimensi yang sudah diberi material

Setelah tahap produksi selesai, dilakukan beberapa evaluasi dan juga revisi sebelum masuk ketahapan berikutnya. Dalam tahap evaluasi terdapat beberapa kali perubahan warna danjuga sudut pengambilan gambar agar didapatkan warna dan juga sudut pengambilan gambar yang paling sesuai dengan media informasi yang akan dibuat. Setelah proses evaluasi selesai maka dilanjutkan dengan tahap post produksi.

Tahap post produksi dimulai dengan tahap rendering animasi 3 dimensi yang telah dibuat. Proses rendering animasi 3 dimensi dilakukan setelah proses modeling, materialing dan juga animating camera sudah dilakukan. Dalam proses rendering output yang dihasilkan dalam format .mp4 agar dapat dilakukan editing pada software editing. Proses rendering dapat dilihat pada Gambar 7.
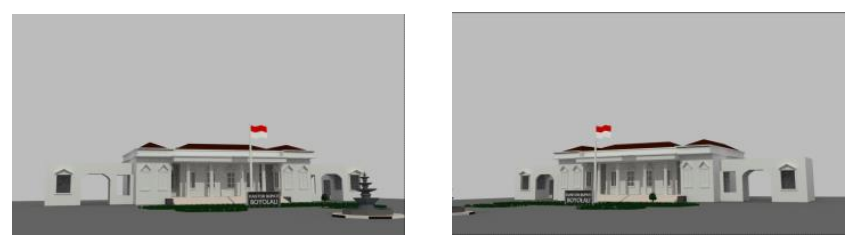

Gambar 7. Proses rendering

Selanjutnya setelah hasil rendering sudah didapat maka proses berikutnya adalah compositing untuk menggabungkan antara animasi yang sudah di render dengan teks informasi yang akan disampaikan pada media informasi ini. Dalam tahap compositing ini juga ditentukan font yang sesuai dengan media informasi ini. Font yang digunakan yaitu jenis font sans serif. Font yang dipilih yaitu Humanst 521 BT yang digunakan sebagai judul dan juga teks informasi. Pemilihan jenis font ini karena font tersebut memiliki karakteristik yang sesuai dengan media informasi dan juga ketebalan dari hurufnya sesuai. Font ini memiliki keterbacaan yang baik sehingga informasi yang ada tersampaikan dengan baik. Font Humanst 521 BT dapat dilihat pada Gambar 8. 


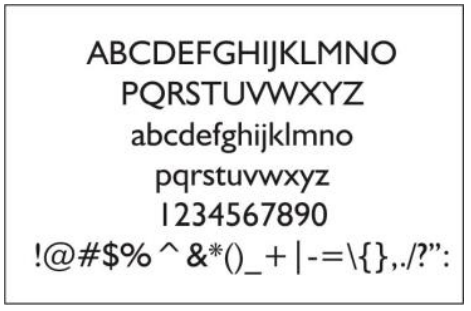

Gambar 8. Font Humanst 521 BT

Selain terdapat tambahan teks, terdapat juga tambahan motion graphic yang dimasukkan dalam media informasi ini. Proses compositing dapat silihat pada Gambar 9.
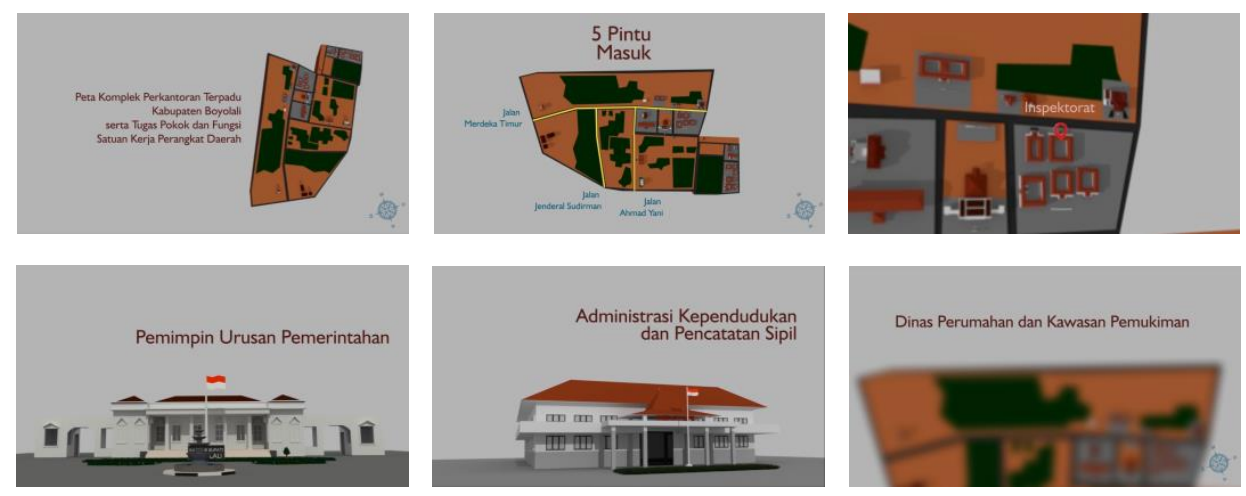

Gambar 9. Proses compositing

Setelah tahapan ini selesai, kemudian dilakukan beberapa evaluasi yang dilakukan oleh Bapak Michael selaku dosen pembimbing, Bapak Sarwanto selaku Kepala Bidang Informasi dan Komunikasi Publik Diskominfo Kabupaten Boyolali, dan kepada tiga responden. Dari hasil evaluasi, ada beberapa hal yang harus di perbaiki seperti jenis dan ukuran font yang terlalu kecil, animating camera, audio dan diperkuat dari segi motion graphic dan juga pemecahan satu video utuh menjadi perbagian sesuai dengan satuan kerja perangkat daerah. Setelah mendapatkan hasil yang paling sesuai, infografis yang telah dibuat dirender menjadi satu video dalam format H264. Setelah itu dimasukkan dalam aplikasi editing film dan audio untuk menambahkan narasi dan backsound yang sesuai. Tahapan terakhir dari proses ini adalah final render untuk mendapatkan hasil yang terakhir untuk diujikan. Hasil render terakhir ini berformat H264.

\subsection{Hasil Pembahasan}

Berikut adalah hasil desain infografis 3D peta komplek perkantoran terpadu Kabupaten Boyolali yang tlah dirancang. Perancangan infografis ini terdiri dari opening, isi dan closing dari masing-masing satuan kerja perangkat daerah. Hasil dari perancangan ini dapat dilihat pada Gambar 10. 

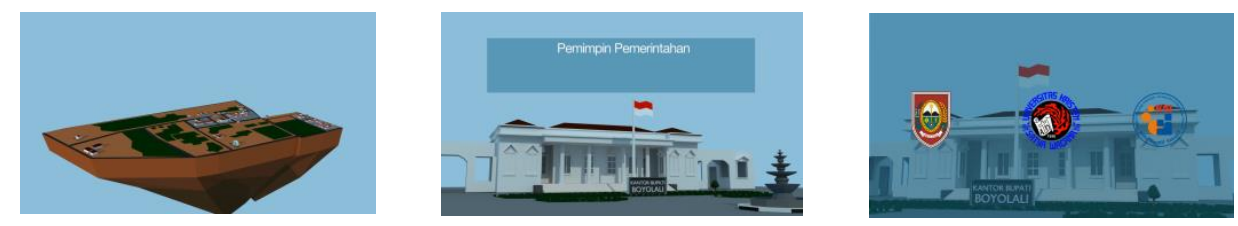

Gambar 10. Desain opening, isi, dan closing

Pada bagian opening video contonya pada kantor Bupati Kabupten Boyolali berisi tampilan seluruh peta komplek perkantoran kemudian ada pergerakan camera menuju depan kantor Bupati Kabupaten Boyolali. Hasil dari perancangan opening infografis dapat dilihat pada Gambar 11.
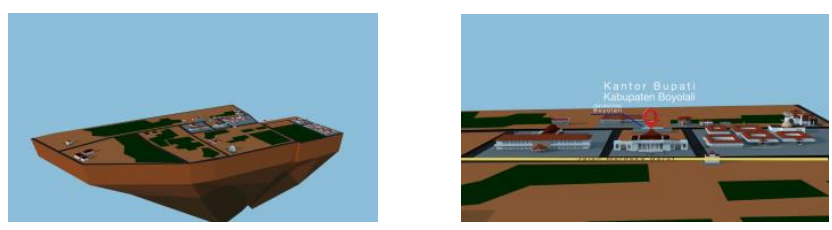

Gambar 11. Desain opening infografis

Selanjutnya pada bagian isi terdapat transisi yang mengarah ke depan gedung kantor untuk memperlihatkan detail dari kantor tersebut dan juga terdapat infografis yang menjelaskan tugas dari bupati. Hasil dari perancangan isi inforafis dapat dilihat pada Gambar 12.
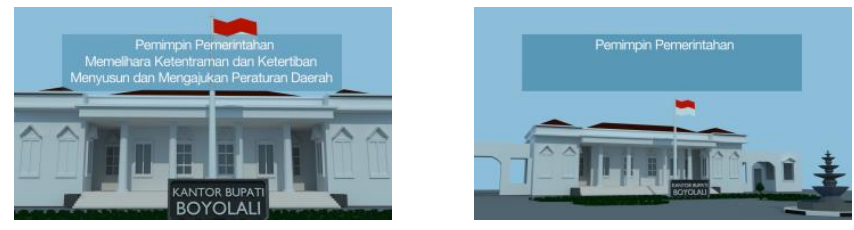

Gambar 12. Desain isi infografis

Pada bagian closing terdapat logo dari Kabupaten Boyolali, Fakultas Teknologi Informasi, dan Universitas Kristen Satya Wacana. Hasil Perancangan closing dapat dilihat pada Gambar 13.

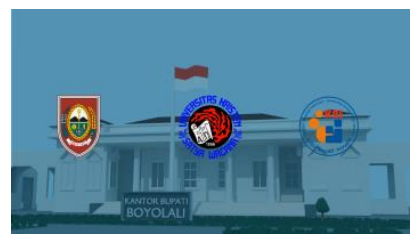

Gambar 13. Desain closing infografis 
Infografis peta komplek perkantoran terpadu Kabupaten Bayolali serta tugas pokok dan fungsi telah diujikan kepada pihak Dinas Komunikasi dan Informatika Kabupaten Boyolali. Pengujian pertama dilakukan dengan melakukan wawancara kepada Kepala Bidang Informasi dan Komunikasi Publik Dinas Komunikasi dan Informatika Kabupaten Boyolali Bapak Sarwanto untuk mengetahui apakah konten yang ada dalam infografis sudah sesuai dengan kebutuhan dari dinas. Pihak Dinas Komunikasi dan Informatika menilai bahwa infografis ini sesuai dengan ketentuan yang diharakan dari Dinas Komunikasi dan Informatika dari segi informasi dan juga desainnya. Infografis ini dinilai telah dapat membantu masyarakat Boyolali dalam memahami peta komplek perkantoran terpadu Kabupaten Boyolali serta tugas pokok dan fungsi dar masingmasing satuan kerja perangkat daerah.

Pengujian kedua dilakukan kepada masyarakat Boyolali yang berada di komplek perkantoran terpadu Kabupaten Boyolali. Masyarakat diberikan kesempatan untuk melihat video infografis dan juga dilakukan wawancara untuk mengetahui tanggapan dari masyarakat tentang video infografis tersebut. Dari wawancara yang dilakukan diketahui bahwa infografis tersebut membantu masyarakat dalam memahami komplek perkantoran terpadu dan juga tugas pokok dan fungsi dari satuan kerja perangkat daerah. Informasi yang termuat dalam video tersebut mudah dipahami dan adanya narasi juga membantu dalam menjelaskan informasi. Dengan demikian, video infografis peta komplek perkantoran terpadu Kabupaten Boyolali serta tugas pokok dan fungsi satuan kerja perangkat daerah memiliki nilai manfaat bagi masyarakat yang memiliki kepentingan dengan dinas atau badan di Kabupaten Boyolali.

\section{KESIMPULAN}

Video infografis peta komplek perkantoran terpadu Kabupaten Boyolali serta tugas pokok dan fungsi satuan kerja perangkat daerah dapat menjadi media baru bagi pemerintah Kabupaten Boyolali dalam memberikan informasi bagi masyarakatnya terkait dengan satuan kerja perangkat daerah. Video infografis tersebut dapat memvisualisasikan Peraturan Bupati tentang tugas pokok dan fungsi satuan kerja perangkat daerah agar lebih mudah dipahami oleh masyarakat. Penambahan teks dan juga narasi memperjelas informasi yang disampaikan. Video infografis peta komplek perkantoran terpadu Kabupaten Boyolali serta tugas pokok dan fungsi satuan kerja perangkat daerah dapat diterapkan pula pada website resmi Pemerintah Kabupaten Boyolali.

Untuk kedepannya, Video infografis peta komplek perkantoran terpadu Kabupaten Boyolali serta tugas pokok dan fungsi satuan kerja perangkat daerah dapat dikembangkan lagi 
menjadi media baru bagi Pemerintah Kabupaten Boyolali dalam menyampaikan informasi, meningkatkan pelayanan dan juga sebagai media yang menarik untuk mensosialisasikan informasi-informasi penting dai pemerintah untuk masyarakat.

\section{DAFTAR PUSTAKA}

Alex Sobur. 2006. Semiotika Komunikasi, Bandung: Remaja Rosdakarya.

Anita, Tri Ayu. 2006. "Perancangan Visual Branding Kabupaten Boyolali Melalui Desain Komunikasi Visual” Surakarta.

Angga Prabawa. 2014. Motion Graphic. http://www.academia.edu/8601077/Motion_Graphic, 19 Mei 2017 .

Ascher, Steven, and Edward Pincus. 1999. The Filmmaker's Handbook: A Comprehensive Guide for the Digital Age. New York: Plume.

Bambang Dwi Marwoto. 2013. Agustus, Pemkab Boyolali Tempati Kantor Baru. http://www.antarajateng.com/detail/agustus-pemkab-boyolali-tempati-kantor-baru-.html, 21 Januari 2017.

Dafi Deff. 2016. Pengertian Motion Graphics dan Cara Membuatnya. http://www.dafideff.com/2016/01/pengertian-motion-graphics-dan-caramembuatnya.html?m=1, 19 Mei 2017.

Husaini Usman dan Purnomo, 2008. Metodologi Penelitian Sosial. http://www.informasiahli.com/2015/07/pengertian-identifikasi-masalah-dalampenelitian.html, 20 Mei 2017.

$\begin{array}{lllll}\text { Kesbangpol Jawa } & \text { Tengah. } & \text { Tupoksi } & \text { Kesbangpol. }\end{array}$ http://kesbangpoljateng.com/portal/profile/tupoksi/, 5 Juni 2017.

Noval. 2015. Metode Penelitian Kualitatif dan Kualitatif, http://www.seputarpengetahuan.com/2015/02metode-penelititan-kualitatif-dan.html, 19 Mei 2017

Pemerintah.Net. 2016. Tugas, Wewenang, Kewajiban dan Hak Kepala Daerah dan Wakil Kepala Daerah. http://pemerintah.net/tugas-wewenang-kewajiban-dan-hak-kepaladaerah-dan-wakil-kepala-daerah/, 5 Juni 2017.

Sarwono, Jonathan dan Harry Lubis. 2007. Metode Riset untuk Desain Komunikasi Visual. Yogyakarta: Andi.

Sukmadinata. 2012. Metode Penelitian Pendidikan. Bandung: PT. Remaja Rosdakarya. 
Ubay. 2016. Pengertian Media Informasi Menurut Para Ahli. http://www.seputarpendidikan.com/2016/04/pengertian-media-informasi-menurut-paraahli.html, 3 mei 2017.

Utari, Rizky. 2014. "Perancangan Video Infografis P.T. Bumi Artha Nugraha Sebagai Media Informasi dengan Teknik Motion Graphic." Yogyakarta

Anonym. 2016. Kedudukan, Fungsi, Tugas, Wewenang dan Hak DPRD. http://www.edukasippkn.com/2016/06/kedudukan-fungsi-tugas-wewenang-dan-hak.html, 5 Juni 2017.

http://oprekzone.com/pengertian-objek-3-dimensi/

www.boyolali.go.id

http://houseofinfographics.com/apa-itu-infografis/ 